\title{
EDITORIAL
}

\section{Vitivinicultura en la región de Tarapacá}

\author{
Winemaking in the Tarapacá Region
}

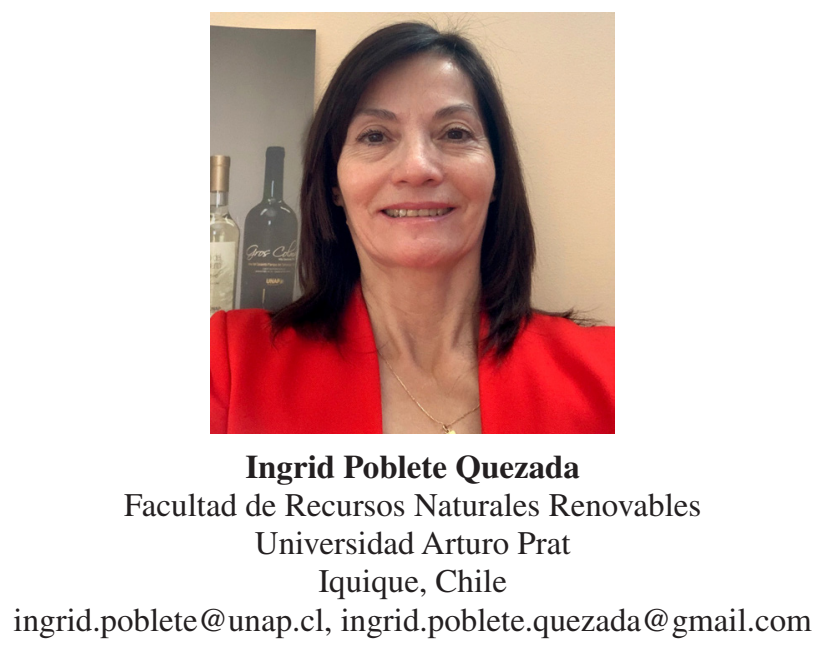

Chile es un país que tiene prestigio y calidad en la producción de vinos, encontrándose en el cuarto lugar a nivel mundial, cuya producción se concentra en la zona centro sur. Sin embargo, en el extremo norte, región de Tarapacá, existe una historia vitivinícola de casi 500 años (s. XVI). En este contexto, destacaron las zonas productoras de Pica y Matilla, ubicada en la precordillera a 1.225 m.s.n.m., caracterizadas por un clima subtropical. En sus inicios, al igual que en otras zonas productoras, las plantas se manejaban con un sistema de conducción en cabeza, caracterizado por un tronco bajo y brotes libres, cultivándose en aquel entonces, las cepas denominadas como Tintilla, Mollar de Granada, Moscatel de Alejandría, entre otras. En estas localidades las plantas se cosechaban en dos oportunidades, temprano en febrero y tardío en mayo, dando origen a distintos tipos de vinos, que incluían vinos dulces, generosos y el más característico el vino "Tipo Oporto", un vino dulce y a la vez con una alta graduación alcohólica. Uno de los grandes vestigios de esta época, lo constituye en la actualidad, el Lagar de Matilla del s. XVIII, declarado monumento histórico nacional en el año 1977, y no sólo a esto debe su importancia, sino que también es el lagar más antiguo preservado en Chile.

La Pampa del Tamarugal, ubicada en la depresión intermedia, en el desierto absoluto, caracterizado
Chile is a country that has prestige and quality in the production of wines, being in fourth place worldwide, whose production is concentrated in the central-southern zone. However, in the extreme north, the Tarapaca region, there is a winemaking history of almost 500 years (16th century). In this context, the production areas of Pica and Matilla, located in the foothills at 1,225 meters above sea level and characterized by a subtropical climate, stand out. In its beginnings, as in other producing areas, the plants were managed with a head training system, characterized by a low trunk and free shoots, cultivating at that time the strains known as Tintilla, Mollar de Granada, Moscatel de Alejandría, among others. In these localities, the plants were harvested in two opportunities, early in February and late in May, giving rise to different types of wines, which included sweet wines, fortified wines, and the most characteristic wine, "Oporto Type", a sweet wine and at the same time with high alcoholic graduation. One of the significant vestiges of this era is the 18th-century Matilla wine press, declared a national historic monument in 1977, which is necessary and the oldest preserved wine press in Chile. 
por suelos con costras salinas y una gran fluctuación térmica diaria, la cual alcanza en el período invernal una amplitud térmica diaria de más de $35^{\circ} \mathrm{C}$, también tiene historia vitivinícola. En estas condiciones, en el s. XX, se produjo vino en la viña "Los Puquios", a $90 \mathrm{~km}$ al SE de Iquique y a 960 m.s.n.m. Aquí toma relevancia la figura de un ciudadano alemán, Enrique Fröelich, quien llegó a la región en 1923 y se estableció en la Pampa, probando diversas especies agrícolas, entre ellas la vid. Es así como establece este viñedo, en la década del 40, empleando el sistema de conducción guíado, en espaldera. El produjo un vino denominado "Canchones", cuya etiqueta, además de las de Pica y Matilla, se encuentra en una colección que posee el tradicional Restaurant el Wagon, en Iquique. Y la Universidad Arturo Prat, cuenta con un ejemplar de vino de esta producción, donado por la hija de Enrique Fröelich, la Sra. Eleonor. El fue un innovador en la agricultura de desierto, tanto así, que en 1938 fue condecorado como Caballero de la Orden al Mérito, por el Gobierno de Chile, por su contribución en esta área. Posteriormente, fue contratado como administrador en la Estación Experimental de Canchones en 1943, en ese entones dependiente de CORFO, y entre sus actividades, establece un viñedo, que aún existe, cuyo nombre varietal se perdió en el tiempo y que en este siglo se identificó como la cepa tinta Gros Colman.

En el s. XXI, resurge la vitivinicultura con el "Vino del Desierto", que considera el rescate de material vegetal, procedente de plantas antiguas, que son producto de esta historia, para recuperar esta tradición vitivinícola, con cepas que tienen identidad regional, incluyendo la tradicional cepa "País", las cepas Gros Colman, Torrontés Riojano y el gran hallazgo del descubrimiento de la cepa Tamarugal, que posee el registro $\mathrm{N}^{\mathrm{o}} 1$, como cepa vinífera chilena registrada por el Serrvicio Agrícola y Ganadero (SAG). Esta vitivinicultura integra cepas patrimoniales, conducidas en espaldera, con un manejo moderno, que incluye la vinificación en cubas de acero inoxidable, lo que en su conjunto se ha traducido en reconocimientos de calidad, con son la obtención de dos medallas de Oro, para la cepa Tamarugal, en concurso Internacional Catad'Or Wines Awards $(2018,2020)$ y la categoría de Súper Premium, con las cepas Tamarugal y Gros Colman, en concurso nacional, Mesa de Cata de La CAV (2020). Esta es la vitivinicultura, emplazada en el desierto más árido del mundo, con un "terroir" único, de la región de Tarapacá.
The Pampa del Tamarugal, located in the intermediate depression in the absolute desert, is characterized by soils with saline crusts and an extensive daily temperature fluctuation. The winter period reaches a daily temperature range higher than $35^{\circ} \mathrm{C}$, also has a history of winemaking. Under these conditions, in the $20^{\text {th }}$ century, wine was produced in the "Los Puquios" vineyard, $90 \mathrm{~km}$ SE of Iquique and $960 \mathrm{~m}$ above sea level. Here the figure of a German citizen, Enrique Fröelich, who arrived in the region in 1923 and settled in the Pampa, testing various agricultural species, including the vine, takes relevance. This testing of agricultural species is how he established this vineyard in the 1940s, using the guided trellis training system. He produced a wine called "Canchones," whose label, in addition to those of Pica and Matilla, is in a collection owned by the traditional Restaurant el Wagon in Iquique. Universidad Arturo Prat has a copy of wine from this production, donated by Enrique Fröelich's daughter, Mrs. Eleonor. He was an innovator in desert agriculture, so much so that in 1938 he was decorated as a Knight of the Order of Merit by the Government of Chile for his contribution in this area. Subsequently, he was hired as an administrator at the Canchones Experimental Station in 1943, at that time dependent on CORFO, and among his activities, he established a vineyard, which still exists, whose varietal name was lost in time and which in this century was identified as the Gros Colman red grape variety.

In the $21^{\text {st }}$ century, viticulture resurfaces with the "Desert Wine," which considers the rescue of plant material from ancient plants, which are the product of this history to recover this winemaking tradition. This is the viticulture, located in the driest desert in the world, with a unique "terroir" of the Tarapaca region. With strains that have regional identity, including the traditional "País" strain, the Gros Colman, Torrontés Riojano, and the great discovery of the discovery of the Tamarugal strain, which has the $N^{o} 1$ registration as a Chilean wine strain registered by the Agricultural and Livestock Service $(S A G)$. This viticulture integrates heritage vines, trained on trellises, with modern management, including vinification in stainless steel vats. As a whole has resulted in quality awards, with two Gold medals for the Tamarugal grape variety, in the International Catad'Or Wines Awards competition $(2018,2020)$ and the Super Premium category, with the Tamarugal and Gros Colman grapes, in the national competition, Mesa de Cata de La CAV (2020). 